\title{
On Uncertainty
}

\author{
JANE TAYLOR \\ Centre for Humanities Research, University of the Western Cape
}

\section{Preamble}

There is some uncertainty written into the form of this paper because, while it seeks to use scholarly procedures in engaging with the philosophical questions provoked by Ludwig Wittgenstein's late speculative essay On Certainty, ${ }^{1}$ it arose out of my research toward a theatrical interpretation of that work. The article is an attempt to stage the mode of thought, as well as the state of mind, of this most complex thinker in his last years. My thoughts pay particular attention to philosophical traditions, while considering dramatic forms, spatial meanings, constellations of persons, histories, ideas, events, and designs.

Moreover, I am locating the text in the context of the workshop, 'Missing and Missed: The Subject, Politics and Memorialisation of South Africa's Colonial and Apartheid Dead' at which it was presented in early 2018. The workshop generated papers and conversations enquiring into the grief, abjection, rage, and discouragement that have marked so much of the violent histories of the twentieth and twentyfirst centuries, and their legacies of colonialism, genocide, and geographic dislocation. The anguish of these materials requires a certain gravitas, and there might seem some waywardness in my exploring the arcane philosophical thought of a young man born into staggering wealth and privilege in Europe at the end of the nineteenth century. Nonetheless, it seems to me that Wittgenstein made a compelling and genuinely traumatised attempt to use intellectual means to come to terms with the precariousness and uncertainty of life in the twentieth century. The depth of his enquiry is read in the following pages alongside some of the details of his 'family romance.'2

I am aware that Wittgenstein's writings have been grouped into two distinct modes: his early work is conceived within the frame of picture theory, and his later writings seek to interpret the world in terms of language games. In both, his thought marked him as an outsider to his own traditions. On thinking about the 'Missing and Missed, I was prompted to reconsider his rather uncanny meditations, his sense of the enigmatic, and magical thinking. How might these have arisen from within the

1 L. Wittgenstein, On Certainty, 1969, G. E. M. Anscombe and G. H. Wright (eds), Denis Paul and G. E. M. Anscombe (trans.), (Oxford: Blackwell, 1975).

2 I mean 'family romance' in the Freudian sense, to allude to the psychic drama of the unfolding of the self inside the nuclear family. Wittgenstein's complex relation to Freud is well documented. On one hand, he was a keen advocate of his Viennese compatriot. This did not prevent him from levelling a clear critique at the Freudian method at times. A striking instance of this can be found in a posthumous collection of his letters, essays and reflections, Culture and Value, G. H. Von Wright (ed.), (Chicago: University of Chicago Press, 1980). Wittgenstein writes, 'What is intriguing about a dream is not its causal connection with events in my life, etc., but rather the impression it gives of being a fragment of a story ... the rest of which remains obscure' (p. 68e). Here the typical Wittgensteinian appeal to obscurity is linked to fragmentation. This is significant as an insight into ideas I am exploring around the haunting of that which is 'missing' in Wittgenstein's thought and experience. 
philosophy and within his life? Here, I invoke his observations about how we inhabit presence and absence within representation and language.

While not seeking to engage in a 'Wittgensteinian reading' (were such a thing were possible), nor undertaking a biographical reading of the philosopher, ${ }^{3} \mathrm{I}$ am trying to imagine what skeins of interpretation and suggestion might be integral to a process of staging Wittgenstein's thought, although not wholly on its own terms. Recent dramatic theory has suggested that the uncanny is necessarily the effect inside one's experience of a dramatic performance, because everything within the theatrical arts has an explicit doubling. Things and persons are simultaneously themselves and a something else. A desk might stand for a policeman's office while it is onstage, yet it may also recognisably be the desk used at a local high school. Moreover there is a complex temporality onstage, which conjures an exquisite presence and absence, ${ }^{4}$ in that every event is based on the actors' 'taking for granted' that everything will, tomorrow at this point in the action, be exactly the same. ${ }^{5}$ That event will mimic this one; and yet, each time it is performed, it is unique to itself - with all of the codes and conventions of cause and effect known, and yet 'as if for the first time.' This is not bad faith; rather it has come to be referred to as 'the suspension of disbelief', and I am inclined to consider Wittgenstein's thoughts about 'certainty' as operating in a similar mode.

Questions about creativity and scholarly service have implications for research and for interpretation. I am interested intellectually in putting some pressure on both modes. At some level, I am asking a Janus-faced question that looks in two directions at once: to what extent is creative exploration of a historical figure legitimate (even necessary) in attempts to apprehend the person and the experience of that figure; and in what ways is the archive a constraint on the creative purposes of the interpreter? (The Wittgenstein archive includes a very diverse body of writings: an extensive biography; secondhand interpretations that amount, at times, to hagiography; profound philosophical debate within linguistics and philosophy; a cinematic poem; ${ }^{6}$ and a film ${ }^{7}$ ). Put differently, my question is, how do scholarly and creative endeavours agitate one another, and what is the potential gain from this?

Wittgenstein's writing is notoriously complex and difficult to apprehend. I am not considering his entire oeuvre. My intentions are very circumscribed. I am seeking to draw some meaning from one of his last papers in order to make a theatre work that might illuminate some spheres within his writing. While I am thinking with and about Wittgenstein's essay, this paper is not a script for that theatrical piece. Rather, this is some of the background research towards the making of that work.

3 There are several such. I recommend two in particular: R. Monk, Wittgenstein: The Duty of Genius (London: Vintage, 1991) and Alexander Waugh, The House of Wittgenstein: A Family at War (New York: Anchor, 2009).

Freddie Rokem, Samuel Weber, and Marvin Carlson have all written on various aspects of these questions.

5 In the past several decades, this convention of iterability has been challenged by performance art, which sets itself apart from acting largely around the conception that each performance is a one-off; the classic text on this question is still, R. Goldberg, Performance Art: From Futurism to the Present, 3rd ed. (New York: Thames \& Hudson, 2011).

6 This fascinating 1992 response to Wittgenstein's Tractatus by Péter Forgács, is available on YouTube.

7 The credits for the 1993 film Wittgenstein give an indication of how much is at stake in any engagement with Wittgenstein: the film was directed by Derek Jarman, scripted by Jarman, Terry Eagleton and Ken Butler, and produced by Tariq Ali. 
That is, in this paper, I consider the relationship between research and the varieties of interpretation. The proofs, arguments or evidence I have selected are of a particular mode. They make available a kind of argument arising from the conjunction of Wittgenstein's own psychosexual being with the geopolitical context of his lifeworld and the decidedly individual (if not eccentric) mode of his writing. These considerations are both methodological and theoretical. I am also exploring how ideas can provide the substance of what happens onstage in a performance event. ${ }^{8}$

There are several ways of knowing and of representation, the varieties of which arise most productively, it seems to me, through interpretations that lie on a cusp between the scholarly and the creative. This may be because the archive is inevitably fragmentary or inadequately tested. In postcolonial studies, that archive is substantially asymmetrical, with an obvious bias toward written records. This frequently results in the detailed presence of the colonial voice, and only a conjectural presence of the colonised, who may (at best) be figured through the ventriloquisms of colonial administrators or ethnographic observers. In such cases, what amounts to a 'counterhistorical' set of hermeneutic procedures becomes fruitful. This is where I am interested in what the arts make available, supplementing what is missing in an informed and substantial way.

Wittgenstein wrote notes for the essay On Certainty shortly before his death. What strikes me as provocative and generative about them are the ways in which the philosopher posits that our assurances of the world are sustained more through that which we do not examine than that which we test. Some resonance between this and an Althusserian understanding of ideology seems to occur, although it is hard to imagine a more incongruous pairing of thinkers. ${ }^{9}$

As one of the richest families in Europe at the start of the twentieth century, the Wittgensteins provide a narrative of catastrophe that is somehow symptomatic of an era.

\section{I: On the one hand}

It is World War I. Three brothers are engaged on the Eastern Front. The young men are not fighting side by side, as one might imagine. Rather, each of them is, we may say, in a different battle zone, each in his own war, though they are all fighting on the side of the Habsburgs. Sons of one of the richest houses of Vienna, their saga becomes significant for history because the youngest of the three is Ludwig Wittgenstein, who becomes one of the twentieth century's most influential philosophers.

8 Here, I am aware that I am straying into complex terrain, already very thoughtfully considered by D. LaCapra. In 'Review: Reading Exemplars: Wittgenstein's Vienna and Wittgenstein's Tractatus', Diacritics, 9, 2, Summer 1979, 65-82, LaCapra analyses questions that arise through two discrepant readings of Wittgenstein. One is grounded in a close reading of the philosopher's own puzzling and occasionally luminous thinking - often marked by enigmas; the other is a bio-political reading of Wittgenstein as he might be 'understood' through his relationship to fin-de-siècle Vienna. LaCapra's point is that the courage of the philosophy in the Tractatus is that it stands as a testimony to contradictions and unresolved questioning, while Allan Janik and Stephen Toulmin's book, Wittgenstein's Vienna, seems to resolve and explain these issues by locating them within his milieu.

9 It is perhaps no more than a curious accident that the two works were written within a year of one another. For Althusser, this would constitute a political question, while for Wittgenstein it would be a philosophical one, although each would no doubt ('certainly') have an apparatus for interpreting one another's instruments. 
Here, I give a brief account of the three brothers, and their encounters with the war.

Let me begin with the eldest of the three. In October 1918, just weeks before the war ended, Kurt shot and killed himself after the soldiers under his command refused to obey his orders. It seems that his troops, who were largely made up of Czechs, Poles, Croats and Hungarians, no longer saw themselves as members of the AustroHungarian Empire, and instead had begun to identify with the emerging fragmentary states that had already been given autonomy by the emperor. Disinclined to fight for the Habsburgs any longer, the soldiers began to wander off towards their homelands, abandoning Kurt and their station, as the imperial state began to disintegrate.

Suicide was the route of least humiliation for their commanding officer. ${ }^{10}$ Such was Kurt's fate. He was also the third of Ludwig's brothers to commit suicide; two others had died some years before, while Ludwig was just a boy.

The second brother on the Eastern Front is Paul. His story raises many questions of theatrical interest for me, and several of my performance questions arise from his story. Paul was conscripted early in the war, and, in August 1914, during the Austrian assault on Poland, he was captured by Russian troops. In the skirmish, he was shot in the right arm, and lost consciousness. On coming round, he discovered that his arm had been amputated. This would be a grim catastrophe for any of us, but for Paul Wittgenstein, it was distinctly so because he was a concert pianist of some ambition.

His musical ambition was surely part of the family burden. The Wittgensteins were all distinctly oriented toward music: the household had seven grand pianos; Hans, the first-born son, and the first to commit suicide, had been considered a musical prodigy; Ludwig could whistle entire movements from several well-known symphonies; Brahms, Mahler, and Richard Strauss were only the most famous of the many musicians to regularly visit the Wittgenstein household; and musical criticism was part of the family ethos. Paul is reported as having wailed at Ludwig, 'I cannot play the piano when you are in the house as I feel your skepticism seeping towards me from under the door. ${ }^{11}$

Music is surely a major element of the staging of the piece.

The wounded, one-armed Paul was imprisoned for some time in the dread Siberian fortress where Dostoyevsky set his novel, The House of the Dead, and here he had to begin to reckon with the fact of his missing limb. It must have been a kind of therapeutic mania that drove him to set himself the task of re-arranging conventional piano pieces for the left hand, using a makeshift drawing of a keyboard on a crate to think through the placement of fingers on notes. On this 'virtual' piano, he perfected complex fingering, using only his left hand to create the aural illusion of two-handed

10 Various interpretations of the motivations for Kurt's death are outlined in Waugh's House of Wittgenstein. Monk's biography notes simply that Kurt 'shot himself when the troops under his command had refused to obey orders.' Duty of Genius, 11. His footnotes do not indicate his source. This account is one that strikes me as compelling.

11 These biographical elements are largely derived from Monk, Duty of Genius. The considerations about Paul Wittgenstein are informed, too, by B. Howe, 'Wittgenstein and the Performance of Disability', Journal of Musicology 27, 2, Spring 2010, 135-180; and J. O'Rourke, 'Paul Wittgenstein: The One-Armed Piano Maestro of WWI', BBC Arts, 5 November 2014. 
playing. Paul engaged in this drill for up to seven hours a day, and in this process he began to arrange Chopin's Revolutionary Etude for the left hand. ${ }^{12}$

Paul Wittgenstein's transcription of the Chopin work may well have been influenced by the fact that Leopold Godowsky had set several arrangements of Chopin's etudes for the left hand. Godowsky is cited as among the greatest classical pianists in history; it is likely that his left-handed transcriptions were composed in part just because he could play them, and they served as a kind of technical challenge for him. His arrangements are renowned for their technical difficulty and have been called the most impossibly difficult things ever written for the piano. ${ }^{13}$ According to some, 'Godowsky was probably unequalled in independence of hands, equality of finger, and his ability to delineate polyphonic strands' while fellow virtuoso pianist and composer Vladimir Horowitz apparently claimed that six hands are needed to play his Passacaglia. ${ }^{14}$ Although some recordings exist, very few people ever saw Godowsky play - he could not bear performing in public.

There is some suggestion that Paul Wittgenstein would have known of Godowsky's arrangements, and that they spurred him to arrange his own version of Chopin's Revolutionary Étude. Of course, the textures of war, so brilliantly evoked by Chopin, may also have influenced this choice. Chopin's work is a distraught aural response to Poland's failed November Uprising against Russia in 1830 and 1831, and is likely to have had emotional magnitude for a young man who had lost an arm fighting on the Russian Front. Chopin dedicated the piece to his friend Franz Liszt, who (interestingly) had trained the gifted left-handed pianist Géza Zichy. Zichy lost a hand in a shooting accident as a youth. ${ }^{15}$ The work would have resonated with Paul for any number of reasons.

The reader might watch a fragment of this astonishing work, which was composed as Chopin's meditation on the bombardment of Warsaw. Its performance makes us attentive to what the left hand is doing in the playing of the piece. Some performances of the Godowsky left-handed arrangement are available on YouTube, and they are striking to watch and hear by comparison. ${ }^{16}$

\section{II: Philosophy's response; and psychology's too}

Let me turn now to the youngest of the three brothers, the philosopher Ludwig. Before the war, from 1911, Ludwig had been in Cambridge, studying philosophy with Bertrand Russell. When the war broke out in July 1914, Ludwig was with his family in Austria, and tried to leave for Norway. On being prevented from doing

12 Howe, 'Wittgenstein and the Performance of Disability'; O'Rourke, 'Paul Wittgenstein'.

13 See 'Leopold Godowsky Left Hand: Chopin Études and Other Pieces for the Left Hand Alone', n.d., https://www.forte-pianopianissimo.com/Godowsky-Left-Hand.html (accessed 26 June 2018).

14 ThePiano.SG, 'Introduction to Leopold Godowsky, his 53 Studies on Chopin's Études, and Passacaglia', n.d., https://www. thepiano.sg/piano/read/introduction-leopold-godowsky-his-53-studies-chopins-etudes-and-passacaglia (accessed 26 June 2018).

15 E. Blom (ed.), Grove Dictionary of Music and Musicians, Vol IX 5th ed. (Oxford: Macmillan,1954), 414. According to Waugh, Zichy was an acquaintance of Paul's; Waugh, House of Wittgenstein.

16 I am in the first phase of a conversation with Johannesburg pianist Jill Richards, who is passionate about experimental piano performance, and has some familiarity with the left-handed repertoire. 
so, he volunteered for civilian duties, and by August, he had signed up for military service in the Austro-Hungarian army. Back in Cambridge, Russell, who was an earnest pacifist, opposed conscription. Following his conviction for pacifism under the Defence of the Realm Act of 1914, Russell was dismissed from the university and sent to prison for the rest of the war, and later described these experiences in 1922 in his Free Thought and Official Propaganda. It was surely something of a puzzle for Russell when Ludwig, his protégé and someone he admired with an almost total adoration, signed up to fight for Austria.

While Ludwig was manning an anti-aircraft searchlight on a gunboat near Krakow, his diaries record that he was reading Nietzsche's, The Anti-Christ. Promoted to the rank of lieutenant, Ludwig was sent to the Italian Front, where he was captured. $\mathrm{He}$ spent the end of the war as a prisoner, apparently writing notes for his early major work, Tractatus Logico-Philosophicus - a work pretty well unlike anything else in the Western tradition. Wittgenstein's writing is notoriously idiosyncratic, often more like poetry than philosophy. His work has disquieted generations of readers, largely because his enigmatic forms and unlikely idioms do not adhere to known philosophical procedures. Alain Badiou classified him as an anti-philosopher, along with Nietzsche, Lacan and St Paul. ${ }^{17}$

Meanwhile, in England, Ludwig's beloved companion, David Hume Pinsent had gone to Farnborough to train as a test pilot. In 1918, a biplane bomber he was flying spontaneously ripped into five pieces, killing Pinsent and his co-pilot. No trace of Pinsent's body was ever recovered, despite a (presumably extensive) search by 1200 soldiers that included the dragging of a canal. Wittgenstein was desolate at the death, and, three years later, dedicated his Tractatus to Pinsent. ${ }^{18}$

Wittgenstein's Tractatus swerves between contesting idioms to denote representation, activating the terms vorstellen, dastellen and abbilden in different instances. Wittgenstein also uses the term bedeuten (to mean, to stand for, to signify) for the ways in which a name refers to an object and for the way in which philosophy obliquely indicates the unsayable. ${ }^{19}$ Wittgenstein's work is irresistibly metaphysical in many of its guises. ${ }^{20}$ Wittgenstein also demonstrates a quite extraordinary apprehension of the complex ordering of worlds that are simultaneously active. He notes, for example, that 'the description of a wish is ... the description of its fulfilment.' This suggests that the material world and its representations are mutually 'entangled. Here I allude expressly to that term as invoked by the title of this special edition 'Missing and Missed. I also acknowledge that the concept of 'entanglement' emerged from within a philosophical tradition associated with quantum theory and the uncertainty principle.

Alain Badiou, Wittgenstein's Anti-Philosophy, Bruno Bosteels (trans.) (New York and London: Verso, 2011).

A detailed chronology is available at www.wittgensteinchronology.com.

LaCapra, 'Reading Exemplars', 76.

On the various guises of Wittgenstein's writings: only his Tractatus was published in his lifetime. His other impactful and significant writings are in letters, or in the celebrated 'notebooks' written up by scholars who attended his classes - a group who have, perhaps unfairly, been identified as disciples. The writings are not standard philosophy, but in the nature of epigram, such as Pascal wrote - leaving readers to 'find' a skein of thought across diffuse iterations collected at various times. 
In 1939, when the Cambridge philosopher G. E. Moore set out to refute real-world scepticism (that is, doubt about the substantial reality of a knowable material world), he held up his one hand while asserting the premise that: 'Here is a hand'. He then raised his other hand stating, 'and here is another'. With this demonstration, he believed himself to have shown that the world is not mind-dependent. ${ }^{21}$ Over several years, Wittgenstein, also at Cambridge, had engaged in fierce discussion with Moore - who was a long-standing interlocutor - although Wittgenstein's comments on Moore might suggest that they were antagonists in an archaic agon. For example, Wittgenstein said of Moore, 'he shows you how far a man can go who has absolutely no intelligence whatsoever. ${ }^{22}$ I suspect this was a measure of Wittgenstein's regard Moore was so close to Wittgenstein in his question, that Wittgenstein could not bear that they were so far apart in method. ${ }^{23}$

Moore's well-known observations on the hand were clearly in Wittgenstein's mind when, late in his career, he wrote his last work, On Certainty. As if in direct response, Wittgenstein's essay begins, 'If you do know that here is one hand, we'll grant you all the rest. ${ }^{24}$ Which he then qualifies with the enigmatic 'From its seeming to me - or to everyone - to be so, it doesn't follow that it is so.' For Wittgenstein 'seeming' and 'knowing' are different orders of thought. In his terms, 'Knowledge' and 'certainty' belong to different categories. ${ }^{25}$

This speculative reasoning opens the way for profound instability about verifiable fact, in terms such as had been posited in physics by the uncertainty principle. What is more, the emerging practice of prosthetics, which became well-established as a result of the ghastly injuries of World War II, began to alter the stock Cartesian assurances about the threshold of the physical self. Sigmund Freud developed the prosthesis into a figure that could act as a support for an idealisation of a fragmented self.

Long ago [man] formed an ideal conception of omnipotence and omniscience which he embodied in his gods. To these gods he attributed everything that seemed unattainable to his wishes, or that was forbidden to him. One may say, therefore, that these gods were cultural ideals. Today he has come very close to the attainment of this ideal, he has almost become a god himself. Only, it is true, in the fashion in which ideals are usually attained according to the general judgment of humanity: not completely, in some respects not at all, in others only half way. Man has, as it were, become a kind of prosthetic God. When he puts on all his auxiliary organs he is truly magnificent; but those organs have not grown on to him and they still give

21 This event is discussed in the Stanford Encyclopedia of Philosophy and in 'A Discussion Between Wittgenstein and Moore on Certainty' (1939): From the Notes of Norman Malcolm', Mind, 124, 493, January 2015, 73-84. See also, G. E. Moore, 'Proof of an External World', 1939, in G. E. Moore: Selected Writings, (London: Routledge, 2013).

22 Monk, Duty of Genius, 262.

23 For an overview of this encounter, see the entry, 'George Edward Moore: d. From the Ontology of Cognition to Criteriology', in J. Fieser and B. Dowden (eds), Internet Encyclopedia of Philosophy, https://www.iep.utm.edu/moore/\#SH2d (accessed 26 June 2018).

24 Wittgenstein, On Certainty, 2e.

25 Wittgenstein, On Certainty, $\$ 308$. 
him much trouble at times ... Future ages will bring with them new and probably unimaginably great achievements in this field of civilization and will increase man's likeness to God still more. But in the interests of our investigations, we will not forget that present-day man does not feel happy in his Godlike character. ${ }^{26}$

Freud is suggesting that the human subject has found the means through which to strap on psychical prostheses that can console her for perceived lacks, to mask or erase that which is missing. This is an abstract elaboration of an idea that Freud had been considering since the last years of World War I.

We are not in the habit of devoting much thought to the fact that every night human beings lay aside the wrappings in which they have enveloped their skin, as well as anything which they may use as a supplement to their bodily organs (so far as they have succeeded in making good those organs' deficiencies by substitutes), for instance, their spectacles, their false hair, and teeth and so on. ${ }^{27}$

The horizons of personhood are, by convention and common-sense experience, associated with the skin, which is its threshold. Of course, that assertion understates the force of sensory information that penetrates us, in an endless riot of aural, visual, and olfactory information, and sensory thrills or revulsions from outside, which strike us to the core.

Freud's theory was profoundly influenced by his proximity to the war and its wounded. In Part II of his influential essay, Beyond the Pleasure Principle ${ }^{28}$ he describes what he calls, 'traumatic neurosis', which he identifies as arising from sudden disaster, such as a railway accident, or the terrible war, which had just ended. He was seeking to interpret the increasingly prevalent phenomenon that has subsequently been identified as 'shell shock', noting 'that the same symptoms sometimes came about without the intervention of any gross mechanical force. ${ }^{29}$ In other words, a subject might experience the trauma of a disabling physical catastrophe without any manifest physical wound or disability. One might in such cases suggest that even the 'originating episode' is missing.

The first are images of early facial prostheses from World War I (Figures $1 \& 2$ ) used to conceal shattered bone and flesh; the second is an image (Figure 3 ) of the oral prostheses that Freud had to wear, once cancer had begun eating away the inside of his mouth. Only his daughter Anna was allowed to help him with the grim task of managing these. 


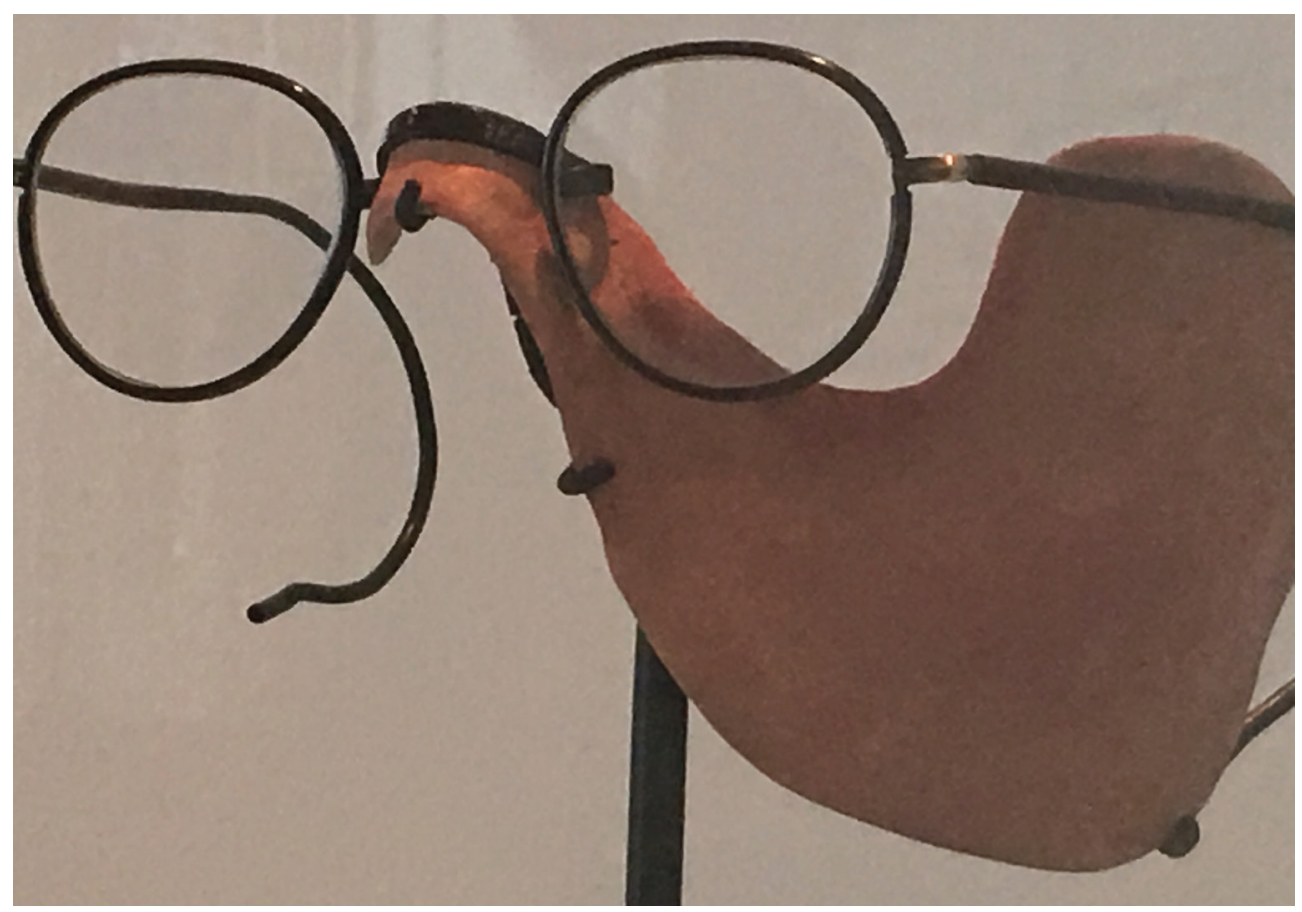

Figure 1

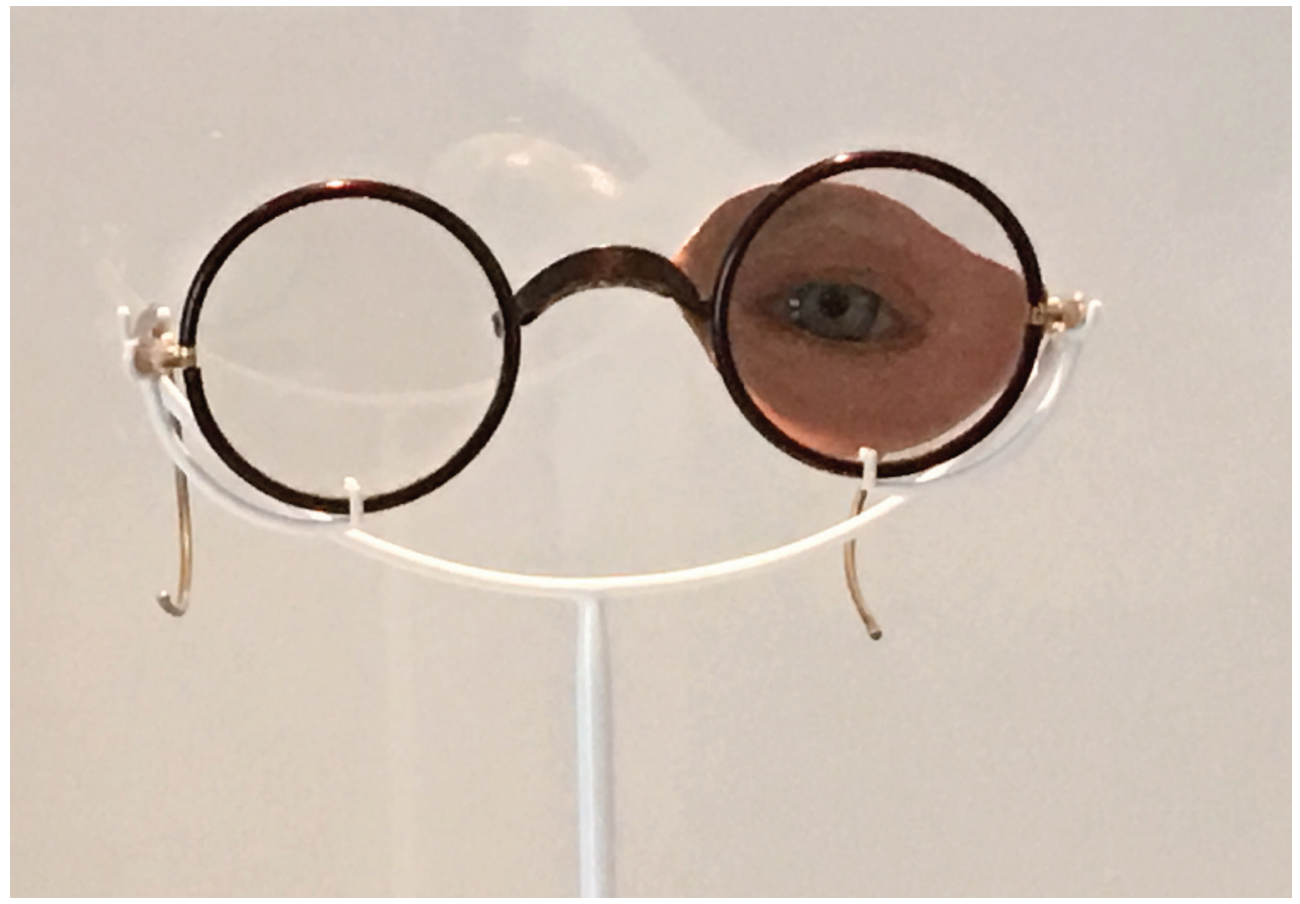

Figure 2

Figures 1 and 2: Prostheses made to conceal shattered bone and flesh associated with World War I injuries as seen in the exhibition, The Body Extended: Sculpture and Prosthetics at the Henry Moore Institute in Leeds (2016). Photograph by Jane Taylor. 


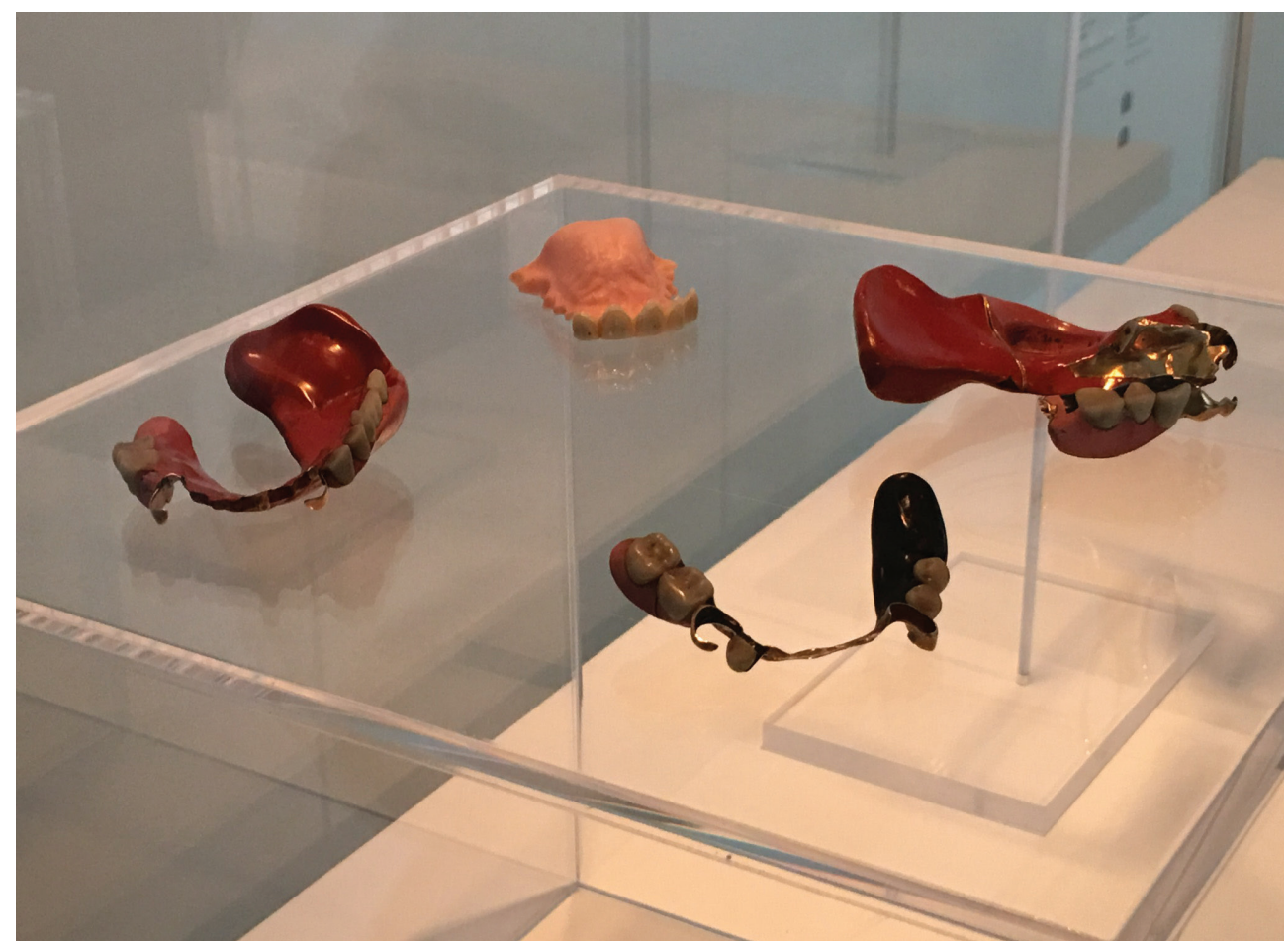

Figure 3: Collection of prostheses worn by Sigmund Freud after repeated surgeries for oral cancer had eroded large areas of his mouth, as seen in the exhibition, The Body Extended: Sculpture and Prosthetics at the Henry Moore Institute in Leeds (2016). Photograph by Jane Taylor.

Wittgenstein's On Certainty is a curious work, in which the philosopher distinguishes between 'facts' we know, but that can and must be subjected to verification and testing, and things of which we are certain. The certainties are such propositions for which the principle of testing makes no sense. As noted, the unsettling opening sentence of this text is, 'If you do know that here is one hand, we'll grant you all the rest.' He follows this up with, ' $\$ 9$. Now do I, in the course of my life, make sure I know that here is a hand - my own hand, that is?' If any readers are prompted to read On Certainty, they will be astonished to discover how often the philosopher returns to the hand as his exemplary question:

\$23: If I don't know whether someone has two hands (say, whether they have been amputated or not) I shall believe his assurance that he has two hands, if he is trustworthy.

\$24: The idealist's question would be something like: 'What right have I not to doubt the existence of my hands?' 
$\$ 40$ : Upon 'I know that here is my hand' there may follow the question 'How do you know?' And the answer to that presupposes that this can be known in that way. So instead of 'I know that here is my hand,' one might say 'Here is my hand', and then add how one knows.

\$41: 'I know where I am feeling pain', 'I know that I feel it here' is as wrong as 'I know that I am in pain.' But 'I know where you touched my arm' is right.

\section{III: Of loss}

Wittgenstein's early great love, David Hume Pinsent, was a descendant of the Scottish philosopher David Hume, after whom he was named. The philosopher Hume suggested that there is only an internal claim to external reality, asking: 'What causes induce us to believe in the existence of body?' He also questioned, 'why we attribute a continu'd existence to objects, even when they are not present to the senses?'30

These are very much the sort of questions addressed by Wittgenstein. Perhaps these Humean questions were discussed by the two men before David disappeared, literally without trace?

After the war, Paul Wittgenstein, for whom 'money was no object', commissioned a spectrum of his era's great composers to write works for the left-handed piano player. Korngold is the first; then Ravel, Prokofiev, Hindemith, Britten, and Strauss all receive commissions. Generally, Paul was unhappy with the compositions, and his dialogues with the composers were often fractious. Somehow it seems, the compositions revealed too much and not enough that the works were for a one-handed player. Here the significance of 'passing' is worth consideration. Paul Wittgenstein is in all likelihood named after St Paul - the most famous converso in Western history, and one of Badiou's anti-philosophers.

What's in a name? The grandfather, Hermann Christian Wittgenstein had converted from Judaism to Catholicism. One might be tempted to ask why their father, a man with Jewish ancestry whose family had assimilated through marriage into Viennese aristocracy, would manifest a conspicuous trace, in his son's name. By naming his son Paul - after a Jew, who was also a Roman citizen, and who spent his early career as a persecutor of Christians but later became a patriarch of the Christian church - he seems to declare that his family is 'passing'.

Chapter 9 of the Book of Acts in the New Testament provides an account of Saul's conversion. He is on the road to Damascus when he is thrown to the ground by a burst of sunlight, and a great voice demands to know, 'Why persecutest thou me?' 
We must imagine - Paul is rendered helpless, blind, and effectively without sensory stimulus. We are told that he neither ate nor drank during this traumatic period. When he finally comes back to 'himself', so to speak, he was no longer himself. $\mathrm{He}$ had become his enemy. Paul became the rock upon which the Christian Church was founded, declaring that henceforth there was neither Greek nor Jew, and asserting that circumcision of the flesh should cease in favour of circumcision in the soul.

By the mid 1930s, Paul Wittgenstein had become a one-armed pianist who could no longer move freely through his beloved Vienna because of the signs declaiming 'Juden verboten'. At first, he tried to get assurances that the family would, as good assimilated citizens, be treated as Aryans; Paul was astonished to discover that this was not the case. 'We count as Jews!' was his cry, on reading the Nazi legislation on genealogy and race. ${ }^{31} \mathrm{He}$ then antagonised several family members by trying to negotiate with the Nazis, and offering to pay for the family's status to be 'reassigned'.

Paul ultimately fled to New York at the start of the Anschluss in 1938. Decades later, one of his former students, Erna Otten, wrote to neurologist Oliver Sacks about her youthful encounter with her piano teacher. We are reminded again of the extraordinary entanglement of mind and flesh through her recollections:

As a very young student of the Viennese pianist Paul Wittgenstein ... I had many occasions to see how involved his right stump was whenever we went over the fingering for a new composition.

He told me many times that I should trust his choice of fingering because he felt every finger of his right hand. At times I had to sit very quietly while he would close his eyes and his stump would move constantly in an agitated manner. This was many years after the loss of his arm. ${ }^{32}$

It is striking that Paul, from so wealthy a family, did not avail himself of the latest technologies in prosthetics development. Photographs show his empty right sleeve tucked neatly into the right-hand pocket of his jacket.

However, a search for information on Paul Wittgenstein on the internet discloses that his legacy lives on in the numerous compositions he commissioned for the onehanded player. We can effectively consider these works to be Paul's prosthesis. It is worth considering why he seems to have found fault with all the compositions that were intended to relaunch his career as a concert pianist. If we acknowledge that a prosthesis is a reminder of loss as much as it is a substitution, we might ask, are the compositions too obviously or not sufficiently evidently, created for the one-handed player? Paul certainly strove to be a piano player, rather than a one-handed pianist. There is a vexing ambiguity implicit in this. Each composition must fail because it could not return the missing arm. No matter how deft the composition, it would 
fail to repair an irrecoverable loss. Was Paul trying to locate a composition through which he might 'pass' for a two-handed pianist?

As we know, Freud's meditations in Beyond the Pleasure Principle prompted a series of subsequent considerations on the phantasmic, the symptom, and trauma. Recent research involving 'mirror neurons' demonstrates that the mind can be persuaded of what it does not want to know. In some cases, individuals who experience persistent pain in a phantom limb (a limb lost in some kind of catastrophic event) can be meaningfully treated if they view their remaining limb in a mirror, and see it respond to treatment as if it were the phantom one. For example, seeing the remaining hand relaxing can fool the mind into unclenching a phantom fist that has been frozen in a rictus for several years. Enigmatically, the brain can relearn what it knows to be true. The same research suggests that mirror neurons in the premotor complex might also be responsible for empathy. Thus, when I observe a behaviour, I can form a mental picture of that behaviour in my mind, and place myself in the position of the other. ${ }^{33}$

An interesting set of considerations has come to my attention through studying lefthanded concerto compositions. Many of the pianists who play such compositions are two-handed. They undertake the performances as virtuosic displays and expressive interpretations. A few perform Godowsky's left-handed Studies on Chopin's Etudes as part of their standard repertoire - demonstrating left-handed dexterity, a left-handed (or sinister) right-handedness. Another group of pianists who engage with these compositions have both hands but are functionally left-handed. They are afflicted with focal dystonia, a neurological condition caused by the 'misfiring' of neurons in the sensorimotor cortex, the layer of neural tissue covering the brain. In such cases, prolonged use of the left hand in and practice and performance creates a distorted 'map' of the hand in the brain.

How do these emerging neurological models of the mind, with their metaphorical 'maps' of the hand in the sensorimotor cortex, take us back to the dualistic riddles of early modernity? What is the hand at the end of my arm, and how does it relate to the hand in my mind? ${ }^{34}$

\section{IV: Certain uncertainty}

You will recall that Ludwig's brother, Kurt, killed himself while serving as an officer in the war, and that he was the third of the three older Wittgenstein brothers to do so. Hans (the musical prodigy) and Rudi, had preceded their sibling in acts of self-extinction. In 1902, Hans fled to America and seems to have drowned himself

33 See the interview with neuroscientist V. S. Ramachandran, 'Do Mirror Neurons Give Us Empathy?' Greater Good Magazine, 29 March 29, 2012, https://greatergood.berkeley.edu/article/item/do_mirror_neurons_give_empathy (accessed 26 June 2018).

34 Mark Hallet, 'Neurophysiology of Dystonia: The Role of Inhibition', Neurobiology of Disease 42, 2, 2011, 177-184. The dystonia, it is assumed, arises from a combination of genetic factors as well as environmental modifiers. As Hallet notes, 'Task specificity is a fascinating clinical problem, but its physiology is not well known' (p. 177). It is, in his description, frequently associated with a highly developed repetitive action. 
in Chesapeake Bay. Two years later, Rudi walked into his favourite bar in Vienna, ordered a glass of milk, laced it with cyanide and swallowed it. In the days leading up to this, he reportedly sought help from the Scientific-Humanitarian Committee, led by Dr Magnus Hirschfeld, which was campaigning against Paragraph 175 of the German Criminal Code, which prohibited homosexual sex. It seems Rudi was terrified that he might be identifiable, and therefore inadvertently exposed, as a subject of Hirschfeld's research. After Rudi's death, his father forbade the family to ever mention his name.

These events were observed by, and became part of Ludwig, the youngest of the children, heir to his share of the family fortune, and to his share of the family curse. No wonder he renounced his inheritance. The whole grim saga has the brooding sense of the inevitable that we know from Greek dramatic form.

Ludwig had observed the suicide of three brothers, each of whom would in turn have been a lost continent in the familial atlas; he observed too, the reparations ongoing in his brother Paul, the pianist who lost his right arm. When I read On Certainty, I am struck by some of the melancholy speculations about the unverifiability of observed events; it is haunted work. For example:

\$90. 'I know' has a primitive meaning similar to and related to 'I see' ('wissen', 'videre'). And 'I knew he was in the room, but he wasn't in the room' is like 'I saw him in the room, but he wasn't there.' 'I know' is supposed to express a relation, not between me and the sense of a proposition (like 'I believe') but between me and a fact. So that the fact is taken into my consciousness. (Here is the reason why one wants to say that nothing that goes on in the outer world is really known, but only what happens in the domain of what are called sense-data.)

In a notebook from 1917, Wittgenstein writes of Dostoyevsky: 'If suicide is allowed, then everything is allowed. If anything is not allowed, then suicide is not allowed.' This from a man who has seen three of his four brothers perish at their own hands. Badiou considers this as an instance of Wittgensteinian 'confessional writing. ${ }^{35}$ I think of it as a kind of 'catastrophic writing, grounded in autobiographical fact yet also working to shift philosophical thought.

In my final observations I would like to return briefly to the idea of 'passing' which I referred to in relation to the converso, and Paul's lost arm.

In 'On Certainty' Wittgenstein notes:

$\$ 79$. That I am a man and not a woman can be verified, but if I were to say I was a woman, and then tried to explain the error by saying I hadn't checked the statement, the explanation would not be accepted. 
These rather enigmatic meditations call to mind the Turing Test, in which Alan Turing, the British mathematical genius responsible for breaking the codes created by the Nazi Enigma machine, sought a way of identifying human from artificial intelligence. He posits a version of the Imitation Game, an old parlour game in which a man (player A) and a woman (player B) are positioned in separate rooms, each with a typewriter. In the original version, they are asked a series of questions, and both try to convince their audience that each is the other. In Turing's version, player A is a machine, and the interrogator has to work out which player is the machine. The paper was published in Mind in 1950.

In 1939, Turing had attended Wittgenstein's Lectures on the Foundations of Mathematics. From the archive of these events, ${ }^{36}$ the two men disagreed on a fundamental question. Wittgenstein was in favour of tolerating contradiction within mathematics; Turing argued against it, positing that the toleration of a contradiction would, in application, lead to the collapse of bridges.

Turing died of cyanide poisoning in 1954; in 1952, he had been convicted of acts of gross indecency and sodomy.

The human subject has always testified to the arbitrary character of loss. Our geniuses give complex accounts of our grief and our resilience in the face of frailty and mortality. Wittgenstein's essay On Certainty can be interpreted as the twentieth century's philosophical 'coming to terms' with a necessary and sustaining suspension of disbelief that grounds the everyday, despite our ever-increasing sense of our own precarity. 